\title{
Effect of the Interpersonal Autonomy-Supportive Teaching Style on the Professional Training of Lifeguards
}

\author{
Irene Castañón-Rubio ${ }^{1}$, Pablo Jorge Marcos-Pardo ${ }^{1, * \mathbb{C}}$, Francisco Cano Noguera ${ }^{2} \mathbb{( 1 )}$ and \\ Juan Antonio Moreno-Murcia ${ }^{3}$ (1) \\ 1 Physical Activity and Sport Sciences Department, Faculty of Sport, Catholic University of Murcia, \\ 30107 Murcia, Murcia, Spain; icastanon@ucam.edu \\ 2 Physical Activity and Sport Department, Faculty of Sport Sciences, University of Murcia, 30720 Murcia, \\ Murcia, Spain; francisco.cano@um.es \\ 3 Sport Science Department, Faculty of Social and Health Sciences, Miguel Hernández University of Elche, \\ 03130 Elche, Alicante, Spain; j.moreno@umh.es \\ * Correspondence: pmarcos@ucam.edu
}

Received: 21 April 2020; Accepted: 21 May 2020; Published: 26 May 2020

check for updates

\begin{abstract}
The objective of this study was to analyze the motivational, behavioral, and cognitive effect of autonomy support in rescue and lifesaving classes within the framework of the self-determination theory. The sample consisted of 40 students aged from 19 to 26 years old $(\mathrm{M}=20.83$; $\mathrm{TD}=1.86)$. Students were randomly divided into the intervention $(n=19)$ and control $(n=21)$ groups. The following were measured: the perception of the autonomy-supportive and controlling interpersonal styles, the social support for the basic psychological needs of the professor, the satisfaction of the basic psychological needs, and the aquatic competence in rescue and lifeguarding. After the application of the program, improvements were observed in the intervention group in the variables of perception of autonomy support, social support for autonomy, and competence; satisfaction of the basic psychological needs for autonomy and competence; and improvement of the cognitive and behavioral processes of aquatic competence in rescue and lifeguarding. The findings show the effectiveness of the interpersonal teaching style of the autonomy-support program by obtaining more positive results at the motivational, behavioral, and cognitive levels, as opposed to a controlling interpersonal style.
\end{abstract}

Keywords: self-determined motivation theory; basic psychological needs; decision-making; teacher; student

\section{Introduction}

Environments and programs that enable the development of teacher autonomy are related to the emergence of motivation and teacher satisfaction. On the other hand, the predominance of a controlling environment in the classroom can frustrate it [1], causing maladaptive consequences for students [2]. The use of these programs implies not only increasing the student's level of autonomy, but also their competence and social relations, as well as the development of self-determined behavior [3]. This interpersonal style is named autonomy-supportive [4], and it has been corroborated by numerous research studies [5] in the last decade. This model facilitates student decision-making, with some studies [6-8] showing the relationship between decision-making and a proactive model in the search for the satisfaction of basic psychological needs (BPN). The effects of motivational orientations on decision-making have been previously analyzed [6], highlighting the need to satisfy the BPN to improve the decision-making processes, due to the positive relationship between improved motivation, 
satisfaction of needs, and learning from decision-making processes. Thus, taking into account motivational processes based on the self-determination theory (SDT) $[9,10]$, the study of and work on decision-making processes is deemed important. One of the professional activities where very important decisions have to be taken is that of lifeguarding. Due to the interest in understanding the effect of an interpersonal style of support for autonomy, where a decision is sought that is adapted to the desired competence, this study proposes to verify the effect of this style of teaching on students who took the rescue and lifeguard course as part of the curriculum of the Higher Technician in Animation of Physical and Sports Activities [11,12] course and their motivational, behavioral, and cognitive levels.

\subsection{Interpersonal Autonomy-Supporting Style}

The SDT, proposed by Deci and Ryan [9] and Ryan and Deci [13,14], analyzes the study of human motivation by determining the degree to which human behaviors are volitional or self-determined and the origin of their performance, differentiating between autonomous and controlling motivation, and examines the cognitive, behavioral, and affective effects. This theory defends the importance of the evolution of internal human resources for the development of personality and self-regulation of behavior in social contexts, pointing out three BPN of human beings: the need for competence, autonomy, and relatedness with others.

Teacher motivation is linked to student motivation, and as the benefits created in the classroom are parallel, seeing their BPN, intrinsic motivation, and autonomy fulfilled leads to them experiencing greater efficiency, commitment, achievement, and well-being [15,16]. Deci and Ryan [9,17] argue that the social context in which the three BPN develop leads to self-determined behaviors, with the students perceived as autonomous and competent. Supported by SDT, the use of strategies to support autonomy is presented as a model of effective teaching intervention towards the increase of intrinsic motivation, the appearance of autonomous behaviors, and the decrease of controlling manifestations in the students [18]. Some studies [19,20] have applied intervention programs to support autonomy in the classroom, with positive results on the motivational aspects of the student, underlining the need to establish programs that implement strategies to support autonomy in the classroom, due to its positive consequences. In spite of this, there is a lack of a teacher training program that specifies an intervention protocol where the criteria of the different research studies on this topic are unified. Cheon, Revee, Lee, and Lee [21]; Moreno-Murcia, Conde, and Sáenz-López [22]; and Reeve [4] indicate that teachers who support autonomy do so by involving the student in the decision-making process, employing a more inquisitive methodology through problem solving, giving more importance to the process than to the outcome, allowing different rates of learning, nurturing internal motivational resources, providing explanatory foundations, using non-controlling language, and showing patience. The opposite of supporting autonomy is control, and this is exercised by teachers who, during instruction in interpersonal behaviors, proclaim that the tasks are to be fulfilled according to their way of thinking, feeling, or behaving. When teachers use a controlling style, student participation is regulated primarily by external contingencies, and pressure is exerted through verbal and nonverbal communication, not by internal motivational resources. Revee, Cheon, and Jang [23] defend the importance of providing the teacher with autonomy support instruction so that the teacher can create environments that support autonomy in the classroom by virtue of their effects, thereby avoiding controlling behaviors due to their negative connotations. An example of this can be seen in some training programs [24].

\subsection{Decision-Making in Sports}

During the playing of a game, the decision-making process does not depend solely on individual capacity, but on the circumstances that surround it and other people that could possibly intervene. This is why players must develop perception processes focused on the possible stimuli that are found and, taking into account their characteristics, establish the best-adapted decision-making process to solve the situation in an adequate manner [6]. In open skills sports, the person is obliged to offer, on a 
continuous basis, alternative solutions to the different situations presented by the game according to its development, taking into account the characteristics of open skills sports and types of knowledge [25]. In this sense, lifeguarding is an open modality, since the lifeguard must perceive and process a large number of stimuli, being able to respond and process the information and making the best decision according to the problem that arises. To do this, the student should be trained in this direction, and not only at the technical level, because in order to make the best decision (analysis of the situation and solution of the problem) he or she has to choose the correct action to be taken to solve it, safeguarding both the victim and his or her own life, successfully resolving the situation. Studies in collective sports show the positive effect of work focused on decision-making [26]. Zeenlenberg, Nelisseng, and Pieters [27] have studied the connection and influence between decision-making and motivational processes. However, despite this, teaching models continue to predominate where ability is isolated from the real-life situation [28], denying the development of decision-making skills [29].

\subsection{The Present Study}

Due to the scarcity of studies within the framework of rescue and lifeguarding and following the recommendations by [6] on the need to analyze decision-making from the perspective of motivation within the framework of the SDT [9] by virtue of its influence on the psychological factors of the human being, the objective of this research was to test the effects of applying an intervention with an interpersonal autonomy-supportive style of teaching in rescue and lifeguarding classes in vocational training at the motivational, behavioral, and cognitive levels. Based on previous research with a methodological intervention to support autonomy $[18,19,30,31]$ it is postulated that an interpersonal autonomy-supportive style of teaching has positive consequences on the satisfaction of BPN, the perception of social support for BPN, and aquatic competition in rescue and lifeguarding.

\section{Survey Methodology}

\subsection{Participants}

Initially, the sample comprised 56 students between the ages of 19 and $26(\mathrm{M}=20.83 ; \mathrm{TD}=1.86)$ who took the Lifeguarding and Aquatic Rescue class as part of the Advanced Technician in Animation of Physical and Sports Activities curriculum in the second course of vocational training. Due to experimental abandonment caused by students dropping out of class, illness, or lack of data, a total of 40 students completed the entire intervention process. Participants were randomly divided into an intervention group $(n=19)$ and a control group $(n=21)$; the percentage distribution according to sex was $22.5 \%$ for girls $(n=9)$ and $77.5 \%$ for boys $(n=31)$.

\subsection{Measurements}

\subsubsection{Support for Autonomy}

The autonomy support scale [32] was used in this study. This scale is composed of 12 items that measure, in a single factor, the support for autonomy perceived by students from their teachers in lifeguarding classes. The items (e.g.,"Throughout the class he invites us to make proposals and values ideas and suggestions") were preceded by the previous sentence "My teacher in lifeguarding class...". This was measured through a Likert scale ranging from 1 (Strongly Disagree) to 5 (Strongly Agree). This study obtained a Cronbach's Alpha reliability coefficient of 0.82 for the pre-test taking and 0.81 for the post-test taking.

\subsubsection{Controlling Style}

The student controller style scale was used [33]. This scale is composed of eight items that measure the controller style of the students, as transmitted by them in the academic environment, in a single factor. The items (e.g., "I verbally pressure others to perform the activity as I have said") were preceded 
by the previous sentence "I, as a student, when I work in small groups or in lifeguard classes, with respect to my classmates and teachers...". This was measured with a Likert scale ranging from 1 (Strongly Disagree) to 5 (Strongly Agree). This study obtained an internal consistency of 0.66 for the pre-test taking and 0.70 for the post-test taking.

\subsubsection{Basic Psychological Needs}

The Spanish version of the Échelle de Satisfaction des Besoins Psychologiques by Gillet et al. [34], validated for the educational context by León et al. [35], was applied. This scale, called the satisfaction of psychological needs in education (ESNPE) scale, consists of 15 items that measure three dimensions (five items for each dimension): perception of autonomy (e.g., "I feel free in my decisions"), perception of competence (e.g., "I often feel very competent"), and perception of relatedness (e.g., "People around me value and appreciate me"). The answers were evaluated according to a Likert scale from 1 (Strongly Disagree) to 5 (Strongly Agree) points. This study obtained an internal consistency of 0.70 for autonomy, 0.80 for competition, and 0.84 for the relatedness for the pre-test, and in the post-test, $0.68,0.86$, and 0.80 , respectively.

\subsubsection{Social Support}

In order to evaluate the teacher's support for basic psychological needs during classes, a questionnaire of support for basic needs in physical education [36], adapted to the context of rescue and lifeguarding, was available. This questionnaire is composed of 24 items measuring the three dimensions of basic psychological needs: perception of autonomy (15 items), perception of competence (four items), and perception of relatedness (five items). The heading that precedes the items is: "In this kind of ...". The answers were evaluated according to a Likert scale of seven points ranging from 1 (Strongly Disagree) to 7 (Strongly Agree). This study obtained an internal consistency for the pre-test taking of 0.89 for autonomy, 0.84 for competition, and 0.88 for relatedness, and in the post-test, 0.70 , 0.84 , and 0.86 , respectively.

\subsubsection{Aquatic Competence in Rescue and Lifeguarding}

In order to evaluate the students' aquatic competence in rescue and lifeguarding classes, the assessment scale of aquatic competence in rescue and lifeguarding, composed of four items, was used to measure four scenarios with a single factor that measures the decision-making process during the resolution of a practical circuit. This was evaluated with a 5-point Likert scale. The first value of the Likert scale (1) refers to situations in which the lifeguard does not act or does not perform the rescue properly (does not fulfil any premise), and the rest of the scale is followed by the values from 2 to 5 , indicating the total number of premises fulfilled: 2 (one premise), 3 (two premises), 4 (three premises), 5 (four premises). Thus, in each scenario, the scores are added to obtain the total score. If the premise was not resolved, the lifeguard was able to retake control of the rescue and resolve the situation in an adequate manner; therefore, the evaluation of each scenario was carried out independently.

\subsubsection{Interpersonal Style}

To examine the teacher's interpersonal style, the observational scale of Sarrazín, Tessier, Pelletier, Trouilloud, and Chanal [37] was utilized. The scale is composed of eight types of verbal interactions: (1) organizational communication, (2) technical hints given, (3) questions asked, (4) praise, (5) encouragement, (6) statements offering perspective, (7) negative communication and (8) criticisms, which were in turn codified into controlling, autonomous, or neutral behaviors. 


\subsection{Procedure and Research Design}

A quasi-experimental design with control and intervention groups was used. The study was approved by the ethics committee of the Catholic University of San Antonio, Murcia (UCAM), 30020091, and was in accordance with the Declaration of Helsinki.

In order to conduct the project, a meeting was held with the management teams of the selected centers, tutors, and lifeguarding teachers in the chosen geographical area. The procedure to be followed and the purpose of the research study were explained. With the intention of not tainting the study, the groups did not know the objective of the study, and they were told that during the process the classes would be recorded in order to observe the teaching behavior. The questionnaires were completed in a theoretical session, at the end of which the evaluation of aquatic competence in the practical class was carried out following the same protocol after the intervention.

A program was designed for both the control group and the intervention group, setting the same objectives, contents, and number of classes for the subjects. The program was structured into 37 classes, 15 theoretical classes (55 minutes long), 18 practical classes (90 minutes long), and four theoretical-practical classes (90 minutes long) following the same objectives. The control group did not follow any particular type of teaching methodology, while in the intervention group the teacher used a motivating interpersonal autonomy-supporting style. In order to achieve the objectives of the study, a series of strategies supporting autonomy were developed [24] and progressively incorporated [38].

Before starting, the intervention group teacher participated in a workshop on autonomy-supporting/controlling styles of teaching. Motivation concepts marked by Intervention Program with Autonomy Support (IPAS) were taught [24,39], and the most adjusted instructional behaviors were taught through the viewing of class fragment videos to provide higher levels of autonomy-supporting/controlling style.

The classes were filmed, which made the measurement and evaluation of the teacher's coded statements possible in order to identify the most controlling or neutral verbalizations and to change them for others that supported autonomy in the autonomy-supporting group and vice-versa with the controlling style. The Sarrazin et al. scale [37] was used to record the teacher's behaviors in relation to identifying controlling, neutral, or autonomous behaviors. The criterion for identifying the autonomy-supporting style implied that at least $80 \%$ of the total verbalizations emitted were behaviors that used pedagogical strategies with support for autonomy, with the remaining $20 \%$ being neutral or controlling behaviors [40]. Upon completion of the training, measurements were taken in a pilot study of four classes with students not related to the study in order to ensure and assist the teacher in the implementation of each approach (autonomy-supporting and controlling). Intra-observer reliability was $93.2 \%$.

To test the effect of teacher interaction on groups, an analysis of repeated measures was carried out (see Table 1). In the intervention group, an improvement was observed in the perception of the interpersonal autonomy-supporting style $(p<0.01)$ while in the control group, no differences were observed.

Table 1. Analysis of repeated measures with the variables autonomy support and controlling styles.

\begin{tabular}{lcccccccc}
\hline & & $\begin{array}{c}\text { Experimental Group } \\
(\boldsymbol{n}=\mathbf{1 9})\end{array}$ & \multicolumn{3}{c}{$\begin{array}{c}\text { Control Group } \\
(\boldsymbol{n}=\mathbf{2 1})\end{array}$} \\
\hline Variables & $M$ & $S D$ & $\eta^{2}$ & $M$ & $S D$ & $\eta^{2}$ \\
\hline \multirow{2}{*}{ Autonomy support } & Pre & 4.04 & 0.13 & 0.65 & 4.15 & 0.08 & 0.06 \\
& Post & $4.47^{* *}$ & 0.12 & & 4.25 & 0.09 & \\
\hline \multirow{2}{*}{ Controlling style } & Pre & 2.19 & 0.15 & 0.09 & 2.24 & 0.11 & 0.08 \\
& Post & 2.11 & 0.14 & & 2.07 & 0.09 & \\
\hline \multicolumn{3}{c}{ Note: ${ }^{* *} p<0.01}$. & & &
\end{tabular}




\subsection{Data Analysis}

Cronbach's Alpha coefficient was used to verify the internal consistency of each factor. In order to check the homogeneity of the two groups before the intervention, an analysis of variance was carried out with a single factor, of all dependent variables, and as a fixed factor for the group. In order to answer the research questions, an ANOVA with seven repeated measures $(2 \times 2)($ Group $\times$ Time) with all the dependent variables was carried out. The data analysis was performed with the statistical program SPSS v22.

\section{Results}

\subsection{Preliminary Analysis}

In order to ensure the homogeneity of all the variables dependent on the two groups before the intervention, an analysis of variance was performed maintaining the group as a fixed factor. Differences were observed (Lambda de Wilks $=0.36, \mathrm{~F}=0.5 .95 p>0.01, \eta^{2}=0.63$ ) in social support for competition $(p<0.05)$, satisfaction with the relationship with others $(p<0.05)$, and in aquatic competition in rescue and lifeguarding $(p<0.01)$. The scores for the intervention group are higher.

To test the effect of teacher interaction on groups, an analysis of repeated measures was carried out (see Table 1). In the intervention group, an improvement was observed in the perception of the interpersonal autonomy-supporting style $(p<0.01)$, while in the control group, no differences were observed.

\subsection{Effects of the Intervention}

After the application of the autonomy-supporting program (see Table 2), it was observed that the intervention group showed a higher score in the social support for autonomy $(p<0.05)$, social support for competition ( $p<0.05)$, satisfaction of autonomy $(p<0.05)$, satisfaction of competence BPN $(p<0.05)$, and aquatic competence in rescue and lifeguarding $(p<0.01)$. No differences were found in the control group.

Table 2. Analysis of repeated measures of all the study variables.

\begin{tabular}{lccccccc}
\hline & & \multicolumn{2}{c}{$\begin{array}{c}\text { Experimental Group } \\
(\boldsymbol{n}=\mathbf{1 9})\end{array}$} & \multicolumn{3}{c}{$\begin{array}{c}\text { Control Group } \\
(\boldsymbol{n}=\mathbf{2 1})\end{array}$} \\
\hline Variables & & $M$ & $S D$ & $\eta^{2}$ & $M$ & $S D$ & $\eta^{2}$ \\
\hline \multirow{2}{*}{ Social Support autonomy } & Pre & 5.81 & 0.19 & 0.20 & 5.60 & 0.18 & 0.15 \\
& Post & $6.16^{*}$ & 0.12 & & 5.94 & 0.08 & \\
\hline \multirow{2}{*}{ Social Support competency } & Pre & 6.47 & 0.17 & 0.18 & 5.89 & 0.23 & 0.06 \\
& Post & $6.63^{*}$ & 0.14 & & 6.16 & 0.19 & \\
\hline \multirow{2}{*}{ Social Support relationship with others } & Pre & 6.58 & 0.14 & 0.08 & 6.25 & 0.19 & 00.01 \\
& Post & 6.77 & 0.06 & & 6.37 & 0.15 & \\
\hline \multirow{2}{*}{ Satisfaction autonomy } & Pre & 3.68 & 0.14 & 0.21 & 3.53 & 0.13 & 0.11 \\
& Post & $3.94^{*}$ & 0.14 & & 3.32 & 0.14 & \\
\hline \multirow{2}{*}{ Satisfaction competency } & Pre & 4.20 & 0.11 & 0.23 & 4.07 & 0.14 & 0.00 \\
& Post & $4.43^{*}$ & 0.12 & & 4.08 & 0.14 & \\
\hline \multirow{2}{*}{ Satisfaction relationship with others } & Pre & 4.37 & 0.13 & 0.08 & 3.97 & 0.14 & 0.06 \\
& Post & 4.48 & 0.11 & & 4.12 & 0.19 & \\
\hline \multirow{2}{*}{ Aquatic competency in rescue and lifeguarding } & Pre & 2.51 & 0.12 & 0.89 & 1.88 & 0.14 & 0.12 \\
& Post & $4.28^{* *}$ & 0.14 & & 2.07 & 0.20 & \\
\hline
\end{tabular}


During the eight months of the study, six video classes were recorded, both in the intervention group and in the control group. The intervention group, after analysis of the behaviors with the observation scales (see Figures 1 and 2), showed a value above $80 \%$ in the behaviors supporting autonomy in all the films, while the control group values were below $80 \%$ in the behaviors supporting autonomy. To avoid discrepancies between the starting assumptions and what actually occurred in practice, the students' perception of autonomy-supporting and controlling style was also measured. The objective was to obtain information from the students' perspective on the effects of the intervention program utilized, in order to contrast them with the data obtained through observation.

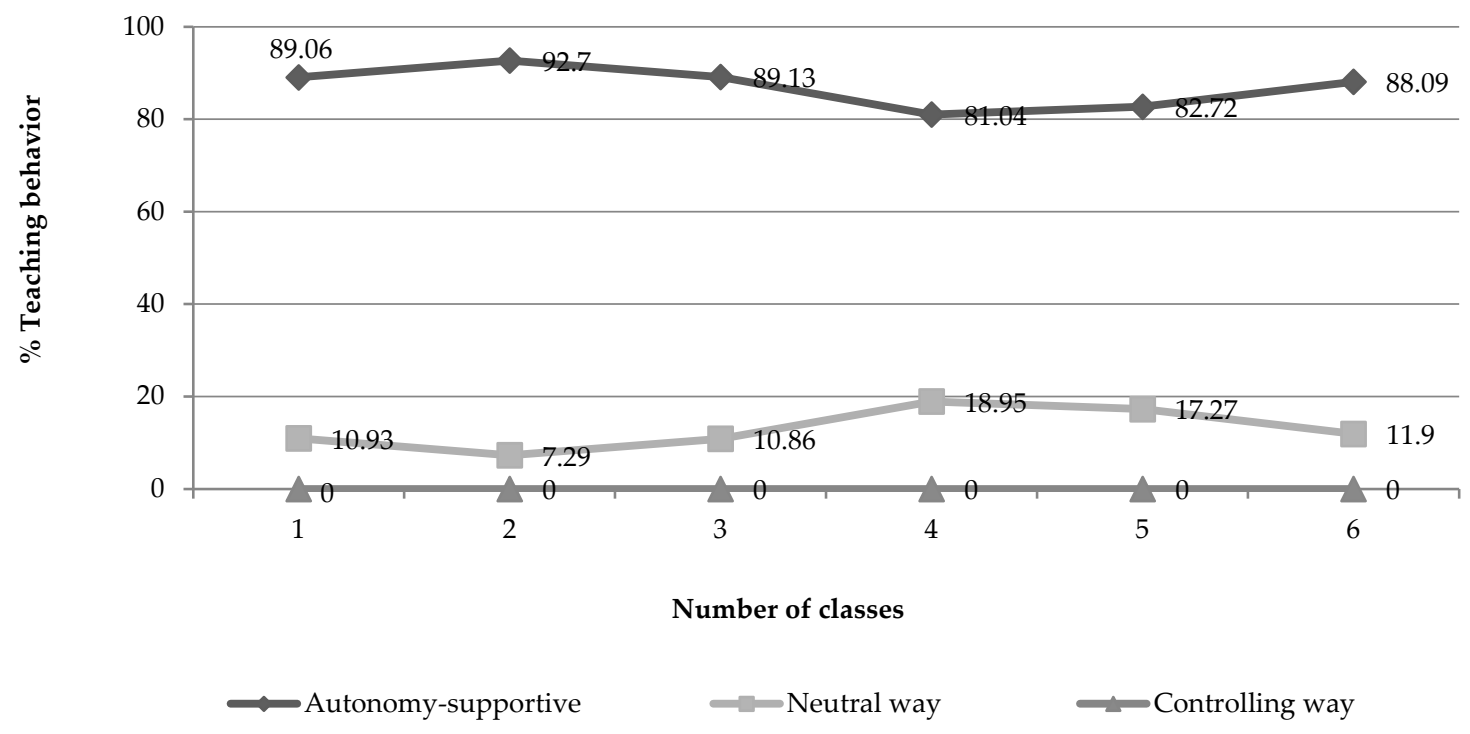

Figure 1. Changes of the percentages of the interpersonal teaching style in the experimental group.

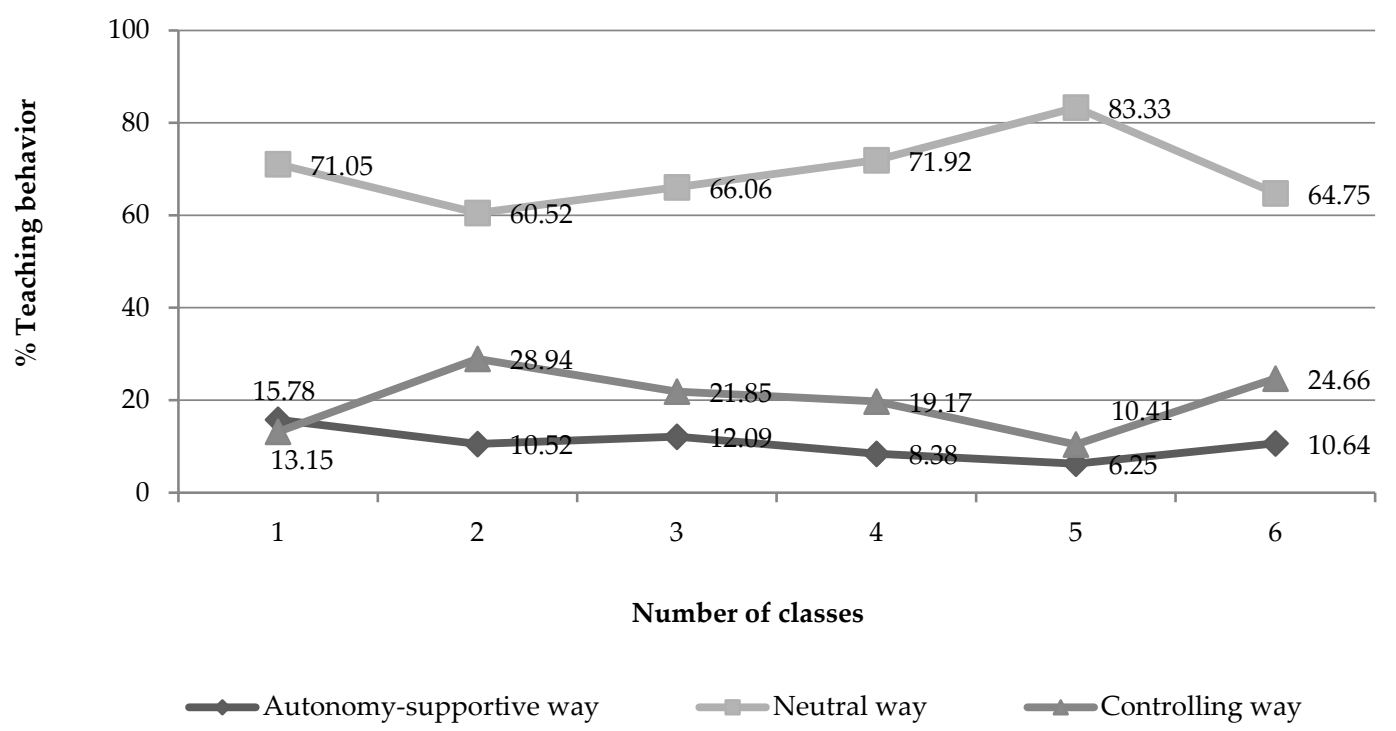

Figure 2. Changes of the percentages of the interpersonal teaching style in the control group.

\section{Discussion}

The role of the teacher in interventions aimed at supporting autonomy, actively involved in the teaching-learning process, led to greater development of thinking skills and work on decision-making processes, and consequently an increase in student autonomy [41]. Students who grow and develop in environments that promote autonomy by participating in the decision-making process are more autonomously motivated [42] because a learning environment based on IPAS, where the teacher favors 
the student's participation in the teaching-learning process and in decision-making, and where each student's effort and progress is monitored within structured and sequenced environments, favors the motivational processes of the student $[3,16,43]$. Therefore, it is vitally important to incorporate teacher training programs and interventions focused on an interpersonal style based on SDT [30] where choice and decision-making are allowed [44] as there is a positive relationship between students' perceptions of the autonomy-supporting teaching style with the satisfaction of the BPN and the autonomous motivation of the student. Therefore, this study aimed to prove the motivational, behavioral, and cognitive effect of the autonomy-supportive teaching style in rescue and lifeguarding classes. Thus, the initial hypothesis is confirmed.

With respect to the variable perception of autonomy-supportive style that students have towards the teacher, an improvement is observed after the intervention, coinciding with the findings by Chang, $\mathrm{Chen}, \mathrm{Tu}$, and $\mathrm{Chi}[45]$ where the perception of support for autonomy and self-determined motivation in physical education (PE) was evaluated. Similarly, Perlman [46] observed changes in the perception of support for autonomy in a sample of PE students, protecting teacher training in support for autonomy as a strategy towards increasing student motivation and better teaching practices due to the positive effect it has on teachers. The results of the study show improvements in both the perception of social support and the satisfaction of the BPN of autonomy and competence, with no differences found in the perception of social support for the need for social relatedness and satisfaction for the need for social relatedness, coinciding with the study by Sevil, Abós, Sanz, and García-González [47]. After the intervention, the results showed that the support for autonomy positively predicted the improvement of the cognitive and behavioral processes of the students by increasing aquatic competence. Previous studies $[48,49]$ support the need to incorporate work-related teaching programs and decision-making skills development in order to achieve optimal performance through improved cognitive processes resulting in positive decision-making and sports expertise [26,50].

In the decision-making process, knowledge facilitates an adequate response [51]. During a rescue, the rescuer must pay attention to numerous stimuli by making choices and determining responses from the moment the victim is detected until the end of the rescue. Alarcón, Castillo, Ureña, Torre, and Cárdenas [52] categorize the creative sportsman as one who has the capacity to constantly modify priorities, showing a high variability in his decisions, thus generating surprising and original answers to the problems he faces, emphasizing tactical creativity as one of the particularities of the players with greater sporting skills. For this reason, decision-making is fundamental for the effectiveness of the rescue, as success or failure depends on it.

This study opens a new line of research where the central axis is the evaluation of the aquatic competition in rescue and lifeguarding according to the rescuer's making of decisions with the objective of effectively solving the problems posed in different situations. However, there are some limitations, such as the low internal consistency in some dimensions, the small number of participants, the fact that the need for social relatedness did not show significant changes, and that motivation was not measured. It is important to allude to the scarcity of studies that analyze the types of sources that influence the teacher's inclination toward a controlling style, namely upward pressure, intermediate pressure, and downward pressure [53]. In this sense, studying the effect of the pressures surrounding the teacher on the model of classroom instruction could clarify the relationship between the perception of social support and the satisfaction of the BPN. In future research, the following is suggested: the addition of the evaluation of the motivation variable to the study, the examination of a larger sample, and checking the effect of the other significant factors such as teachers.

\section{Conclusions}

In conclusion, teaching strategies to support autonomy in lifesaving and lifeguarding classes are presented as a model of effective teaching towards the motivational, behavioral, and cognitive development of the lifeguard. 
Author Contributions: Conceptualization, I.C.-R., P.J.M.-P., F.C.N. and J.A.M.-M.; Data curation, I.C.-R. and J.A.M.-M.; Formal analysis, J.A.M.-M.; Investigation, I.C.-R., P.J.M.-P., F.C.N. and J.A.M.-M.; Methodology, I.C.-R., P.J.M.-P., F.C.N. and J.A.M.-M.; Project administration, I.C.-R. and J.A.M.-M.; Resources, I.C.-R.; Software, I.C.-R. and J.A.M.-M.; Supervision, I.C.-R., P.J.M.-P., F.C.N. and J.A.M.-M.; Validation, F.C.N. and J.A.M.-M.; Writing original draft, I.C.-R. and P.J.M.-P.; Writing - review \& editing, P.J.M.-P., F.C.N. and J.A.M.-M.. All authors have read and agreed to the published version of the manuscript.

Funding: This research received no external funding.

Acknowledgments: We are grateful to students of Samaniego Concerted Teaching Center and Higher Institute of Vocational Training San Antonio de Murcia for their participation.

Conflicts of Interest: The authors declare no conflict of interest.

\section{References}

1. Haerens, L.; Aelterman, N.; Vansteenkiste, M.; Soenens, B.; Van Petegem, S. Do perceived autonomy-supportive and controlling teaching relate to physical education students' motivational experiences through unique pathways? distinguishing between the bright and dark side of motivation. Psychol. Sport Exerc. 2015, 16, 26-36. [CrossRef]

2. De Meyer, J.; Tallir, I.B.; Soenens, B.; Vansteenkiste, M.; Aelterman, N.; Van den Berghe, L.; Haerens, L. Does observed controlling teaching behavior relate to students' motivation in physical education? J. Educ. Psychol. 2014, 106, 541-554. [CrossRef]

3. Su, Y.; Reeve, J. A meta-analysis of the effectiveness of intervention programs designed to support autonomy. Educ. Psychol. Rev. 2011, 23, 159-188. [CrossRef]

4. Reeve, J. Why teachers adopt a controlling motivating style toward students and how they can become more autonomy supportive. Educ. Psychol. 2009, 44, 159-175. [CrossRef]

5. Cheon, S.H.; Reeve, J.; Ntoumanis, N. A needs-supportive intervention to help PE teachers enhance students prosocial behavior and diminish antisocial behavior. J. Sport Exerc. Psychol. Sport Exerc. 2018, 35, 74-88. [CrossRef]

6. Gil, A.; Jiménez, R.; Moreno, M.P.; García-González, L.; Moreno, B.; Del Villar, F. Análisis de la motivación intrínseca a través de las necesidades psicológicas básicas y la dimensión subjetiva de la toma de decisiones en jugadores de voleibol. Rev. Latinoam. De Psicol. Del Deporte 2010, 5, 29-44.

7. Gil, A.; Jiménez, R.; Moreno, M.P.; Moreno, A.; Del Villar, F. Análisis de la Motivación y Aspectos Emocionales y Subjetivos de la Toma de Decisiones en Jóvenes Jugadores de Voleibol; En Actas del III Congreso Euro-americano de Motricidad Humana: Murcia, Spain, 2009.

8. Sevil, J.; Abós, A.; Generelo, E.; Aibar, A.; García-González, L. Importancia de apoyo a las necesidades psicológicas básicas en la predisposición hacia diferentes contenidos en Educación Física. Retos. Nuevas Tend. En Educ. Físicadeportes Y Recreación 2016, 29, 3-8.

9. Deci, E.L.; Ryan, R.M. Intrinsic Motivation and Self-Determination in Human Behavior; Plenum Press: New York, NY, USA, 1985. [CrossRef]

10. Deci, E.L.; Ryan, R.M. The "what" and "why" of goal pursuits: Human needs and the self-determination of behaviour. Psychol. Inq. 2000, 11, 227-268. [CrossRef]

11. Real Decreto 2048/1996, de 22 de Diciembre, por el que se Establece el Título de Formación Profesional de Técnico Superior en Animación de Actividades Físicas y Deportivas y las Correspondientes Enseñanzas Mínimas. Boletín Oficial del Estado, 35, de 9 de Febrero de 1996. Available online: https://www.boe.es/ buscar/doc.php?id=BOE-A-1996-2750 (accessed on 22 September 2019).

12. Real Decreto 1262/1997, de 24 de Julio, por el que se Establece el Currículo del Ciclo Formativo de Grado Superior Correspondiente al Título de Técnico Superior en Animación de Actividades Físicas y Deportivas. Boletín Oficial del Estado, 218, de 11 de Septiembre de 1997. Available online: https: //www.boe.es/buscar/doc.php?id=BOE-A-1997-19616 (accessed on 22 September 2019).

13. Ryan, R.M.; Deci, E.L. Self-Determination theory and the facilitation of intrinsic motivation, social development, and well-being. Am. Psychol. 2000, 55, 68-78. [CrossRef] [PubMed]

14. Ryan, R.; Deci, E. Intrinsic and extrinsic motivations: Classic definitions and new directions. Contemp. Educ. Psychol. 2000, 25, 54-67. [CrossRef]

15. Cheon, S.H.; Reeve, J.; Yu, T.H.; Jang, H.R. The theacher benefits from giving autonomy support during Physical Education instruction. J. Sport Exerc. Psychol. 2014, 36, 331-346. [CrossRef] 
16. Cheon, S.H.; Reeve, J. A classroom-based intervention to help teachers decrease students' amotivation. Contemp. Educ. Psychol. 2015, 40, 99-111. [CrossRef]

17. Deci, E.L.; Ryan, R.M. A motivational approach to self: Integration in personality. In Nebraska Symposium on Motivation. Perspectives on Motivation; Dienstbier, R., Ed.; University of Nebraska Press: Lincoln, NE, USA, 1991; Volume 38, pp. 237-288.

18. Moreno-Murcia, J.A.; Sánchez-Latorre, F. The effects of autonomy support in physical education classes. Ricyde. Rev. Int. De Cienc. Del Deporte 2016, 12, 79-89. [CrossRef]

19. Fin, G.; Moreno-Murcia, J.A.; León, J.; Baretta, E.; Junior, R.J.N. Interpersonal autonomy support style and its consequences in physical education clases. PLOS ONE 2019, 14, e0216609. [CrossRef] [PubMed]

20. Núñez, J.L.; León, J. Determinants of classroom engagement: A prospective test based on self-determination theory. Teach. Teach. 2018, 25, 147-159. [CrossRef]

21. Cheon, S.H.; Revee, J.; Lee, Y.; Lee, J.W. Why autonomy-supportive interventions work: Explaining the professional development of teachers' motivating style. Teach. Teach. Educ. 2018, 69, 43-51. [CrossRef]

22. Moreno-Murcia, J.A.; Conde, C.; Sáenz-López, P. Importancia del apoyo de autonomía en la figura del docente en educación física. Tándem. Didáctica De La Educ. Física 2012, 40, 18-27.

23. Revee, J.; Cheon, S.H.; Jang, H.R. A Teacher-Focused Intervention to Enhance Students' Classroom Engagement. In Handbook of Student Engagement Interventions; Fredricks, J.A., Reschly, A.L., Christenson, S.L., Eds.; Academic Press: San Diego, CO, USA, 2019; pp. 87-102. [CrossRef]

24. Moreno-Murcia, J.A.; Hernández, E.H.; Alonso, J.L.N.; León, J.; Valenzuela, A.V.; Conte, L. Protocolo de estudio cuasi-experimental para promover un estilo interpersonal de apoyo a la autonomía en docentes de educación física. Cuad. De Psicol. Del Deporte 2019, 19, 83-101. [CrossRef]

25. Claver, F.; Jiménez, R.; Conejero, M.; García-González, L.; Moreno, M.P. Cognitive and motivational predictors of performance in game actions in young volleyball players. Eur. J. Hum. Mov. 2015, 35, 68-84.

26. Gil, A.; Moreno, M.P.; Claver, F.; Moreno, A.; Del Villar, F. Manipulación de los condicionantes de la tarea en Educación Física: Una propuesta desde la pedagogía no lineal. Retos Nuevas Tend. En Educ. Física Deporte Y Recreación 2016, 29, 22-27.

27. Zeelenberg, M.; Nelissen, R.M.A.; Pieters, R. Emotion, motivation, decision making: A feeling-is-for-doing approach. In Intuition in Judgment and Decision Making; Plessner, H., Betsch, C., Betsch, T., Eds.; Erlbaum: Mahwah, NJ, USA, 2008; pp. 173-190.

28. Valera-Tomás, S.; Ureña-Ortín, N.; Ruiz-Lara, E.; Alarcón-López, F. La enseñanza de los deportes colectivos en Educación Física en la E.S.O. Rev. Int. De Med. Y Cienc. De La Act. Física Y El Deporte 2010, 10, 502-520.

29. Gray, S.; Sproule, J. Developing pupils' performance in team onvasion games: A comparative study within a Scottish context. Phys. Educ. Sport Pedagog. 2011, 16, 15-32. [CrossRef]

30. Abós, Á.; Serrano, J.S.; Sanz, M.; Aibar, A.; González, L.G. El soporte de autonomía en Educación Física como medio de prevención de la oposición desafiante del alumnado. [Autonomy support in Physical Education as a means of preventing students' oppositional defiance]. Ricyde. Rev. Int. De Cienc. Del Deport. 2016, 12, 65-78. [CrossRef]

31. Escriva-Boulley, G.; Tessier, D.; Ntoumanis, N.; Sarrazin, P. Need-supportive professional development in elementary school physical education: Effects of a cluster-randomized control trial on teachers' motivating style and student physical activity. Sportexerc. Perform. Psychol. 2018, 7, 218-234. [CrossRef]

32. Moreno-Murcia, J.A.; Huéscar, E.; Pintado, R.; Marzo, C.J. Diseño y validación de la escala de apoyo a la autonomía en Educación Superior: Relación con la competencia laboral del discente. Rev. Española De Orientación Psicopedag. 2019, 30, 116-130. [CrossRef]

33. Hernández, E.H.; Moreno-Murcia, J.A.; Alías, A. Diseño y validación de una escala para medir el estilo controlador del estudiante de Educación Superior. Psychol. Soc. Educ. 2017, 9, 239. [CrossRef]

34. Gillet, N.; Rosnet, E.; Vallerand, R.J. Développement dúne echelle de satisfaction des besoins fondamentaux en contexte spotif. Can. J. Behav. Sci. 2008, 40, 230-237. [CrossRef]

35. León, J.; Domínguez, E.; Núñez, J.L.; Pérez, A.; Martín-Albo, J. Traducción y validación de la versión española de la Échelle de Satisfacción des Besoins Psychologiques en el contexto educativo. An. De Psicol. 2011, 27, 405-411.

36. Zamarripa, J.; Castillo, I.; Tomás, I.; López-Walle, J. Validación mexicana del Cuestionario de apoyo a las necesidades psicológicas básicas en la educación física. Rev. Mex. De Psicol. 2016, 33, 143-150. 
37. Sarrazin, P.; Tessier, D.; Pelletier, L.; Trouilloud, D.; Chanal, J.P. The effects of teachers' expectations about students' motivation on teachers' autonomy-supportive and controlling behaviors. Int. J. Sport Exerc. Psychol. 2006, 4, 283-301. [CrossRef]

38. Barrachina-Peris, J. Efecto del Apoyo a la Autonomía en el Enfoque por Competencias en Educación Física. Ph.D. Thesis, Universidad Miguel Hernández, Alicante, Spain, 2017.

39. Deci, E.L.; Ryan, R.M. Handbook of Self-Determination Research; University of Rochester Press: Rochester, NY, USA, 2002.

40. Perlman, D. Assisting Preservice Teachers Toward More Motivationally Supportive Instruction. J. Teach. Phys. Educ. 2015, 34, 119-130. [CrossRef]

41. Kurucan, A. Beden Eğitiminde Psikolojik İyi Oluşun Bağlamsal Temelleri. Pamukkale Univ. J. Educ. 2019, 45, 99-115. [CrossRef]

42. Ward, J.; Wilkinson, C.; Graser, S.V.; Prusak, K.A. Effects of Choice on Student Motivation and Physical Activity Behavior in Physical Education. J. Teach. Phys. Educ. 2008, 27, 385-398. [CrossRef]

43. Lochbaum, M.; Jean-Noel, J. Perceived Autonomy-Support Instruction and Student Outcomes in Physical Education and Leisure-Time: A Meta-Analytic Review of Correlates. [Percepción de la formación de apoyo a la autonomía y resultados en estudiantes en educación física y tiempo libre: Una revisión meta-analítica de correlaciones]. Ricyde. Rev. Int. De Cienc. Del Deport. 2016, 12, 29-47. [CrossRef]

44. Behzadnia, B.; Adachi, P.J.; Deci, E.L.; Mohammadzadeh, H. Associations between students' perceptions of physical education teachers' interpersonal styles and students' wellness, knowledge, performance, and intentions to persist at physical activity: A self-determination theory approach. Psychol. Sport Exerc. 2018, 39, 10-19. [CrossRef]

45. Chang, Y.-K.; Chen, S.; Tu, K.-W.; Chi, L.-K. Effect of Autonomy Support on Self-Determined Motivation in Elementary Physical Education. J. Sports Sci. Med. 2016, 15, 460-466. [PubMed]

46. Perlman, D. Help motivate the amotivated by being a supportive teacher. Phys. Educ. Sport Pedagog. 2013, 20, 204-214. [CrossRef]

47. Serrano, J.S.; Catalán, Á.A.; Remacha, M.S.; González, L.G. El “Lado Claro" y El "Lado Oscuro" de la Motivación en Educación Física: Efectos de una intervención en una Unidad Didáctica de Atletismo. Rev. Iberoam. De Diagnóstico Y Evaluación. 2018, 1, 93-107. [CrossRef]

48. Gil-Arias, A.; Claver, F.; Práxedes, A.; Del Villar, F.; Harvey, S. Autonomy support, motivational climate, enjoyment and perceived competence in physical education: Impact of a hybrid teaching games for understanding/sport education unit. Eur. Phys. Educ. Rev. 2018, 26, 36-53. [CrossRef]

49. Práxedes, A.; Del Villar, F.; Pizarro, D.; Moreno, A. The Impact of Nonlinear Pedagogy on Decision-Making and Execution in Youth Soccer Players According to Game Actions. J. Hum. Kinet. 2018, 62, 185-198. [CrossRef]

50. Pizarro, A.P.; Álvarez, F.D.V.; Domínguez, A.M.; Serrano, J.S.; González, L.G. The effects of a comprehensive teaching program on dribbling and passing decision-making and execution skills of young footballers. Kinesiology 2017, 49, 74-83. [CrossRef]

51. Gil, A.; Del Villar, F.; Claver, F.; Moreno, A.; García-González, L.; Arroyo, M.P.M. ¿Existe relación entre el nivel de competición y el conocimiento del juego en voleibol? Retos. Nuevas Tend. En Educ. Física Deporte Y Recreación 2012, 21, 53-57.

52. Alarcón, F.; Castillo, A.; Ureña, N.; Torre, E.; Cárdenas, D. Creatividad táctica y funciones ejecutivas en los deportes de interacción. Rev. Euroam. De Cienc. Del Deporte 2017, 6, 147-152. [CrossRef]

53. Pelletier, L.; Séguin-Lévesque, C.; Legault, L. Pressure from above and pressure from below as determinants of teachers' motivation and teaching behaviors. J. Educ. Psychol. 2002, 94, 186-196. [CrossRef]

(C) 2020 by the authors. Licensee MDPI, Basel, Switzerland. This article is an open access article distributed under the terms and conditions of the Creative Commons Attribution (CC BY) license (http://creativecommons.org/licenses/by/4.0/). 